\title{
PELARANGAN RIBA DALAM PERBANKAN: IMPACT PADA TERWUJUDNYA KESEJAHTERAAN DI MASA COVID-19
}

\section{USURY PROHIBITION IN BANKING: IMPACT IN THE PROSPERITY OF WELFARE IN THE COVID-19 PERIOD}

\author{
Binti Nur Aisyah, Nur Azrin Yuliani, Evita Amelia, dan Fifin Nasiroh \\ Fakultas Ekonomi dan Bisnis Islam IAIN Tulungagung \\ Jl. Mayor Sujadi No.46, Kedung Waru, Jawa Timur \\ Email: binti.advan@gmail.com, nurazrinyuliani@gmail.com, \\ ameliaevita05@gmail.com fifinnasiroh13@gmail.com
}

Naskah diterima 20 Mei 2020, di-review 03 Juni 2020, disetujui 30 Juni 2020

\begin{abstract}
The aim of prohibiting usury is to protect people who conduct mu'amalah. Indeed, Al qur'an prohibited it because it is resulted injustice. It is obviously felt in the period of Covid-19 Pandemic. The research purpose was to analyze the problems of applying usury system in banking and to analyze the privileges of prohibiting usury system in banking. The descriptive research was used in this paper. The results show usury systems resulted gaps and injustice. Indeed, it is also caused economic instability. A solution for this problem is profit sharing. This system can bring justice and it will lead into economic equality particularly in the era of Covid-19 pandemic. Therefore, by applying Islamic economic system, the economy is more stable and social welfare can be achieved.
\end{abstract}

Keywords: Prohibition of Usury System, Banking and Welfare

\begin{abstract}
Abstrak: Pelarangan riba memiliki dasar dan tujuan yang melindungi segenap masyarakat yang melakukan mu'amalah dan dirasakan dampaknya pada masa pandemi covid-19. Dasar utama riba diharamkan dalam Islam sebagaimana dalam al-qur'an menimbulkan ketidakadilan. Paper ini bertujuan untuk mengulas dan memaparkan masalah penerapan sistem riba pada perbankan dan menganalisis keuntungan dilarangnya riba dalam perbankan. Penulis menggunakan metode deskriptif dalam menganalisis paper ini. Hasil dari paper ini adalah riba menimbulkan kesenjangan dan ketidakadilan bagi masyarakat serta menjadi penyebab ketidakstabilan ekonomi. Nisbah atau profit sharing atau membagikan keuntungan bersih merupakan solusi yang dapat menghindarkan perbankan dalam perbuatan riba menuju kesejahteraan baik bagi nasabah maupun perbankan. Sistem tersebut dapat memunculkan keadilan dan kemerataan ekonomi. Profit sharing dapat menghindarkan perbuatan yang menghasilkan kesengsaraan dan kebinasaan, dan menolong sesama, terutama disaat pandemi covid-19 melanda. Pada akhirnya dengan sistem ekonomi islam, ekonomi lebih stabil dan kesejahteraan masyarakat dapat dicapai.
\end{abstract}

Kata Kunci: Pelarangan Riba, Perbankan dan Kesejahteraan

\section{PENDAHULUAN}

D unia sedang dilanda wabah pandemi corona virus deseases (covid 19). Wabah tersebut memberikan dampak ke seluruh sektor kehidupan, tak terkecuali sistem keuangan.
Dana yang telah disalurkan lembaga keuangan kepada usaha-usaha masyarakat, maupun perusahaan terdampak. Adanya karantina wilayah menyebabkan produk tidak terdistribusi. Hal ini menyebabkan sistem keuangan kita tergerus, termasuk bunga yang ada di bank 
konvensional. Sebagaimana instruksi Gubernur Bank Indonesia (BI), perbankan diharap segera menurunkan bunga kredit (Laucereno, 2020:1)

Instruksi BI di atas ditujukan pada institusi yang terlibat dalam intermediasi pemenuhan kebutuhan modal masyarakat sehingga membutuhkan perhatian khusus pemerintah. Fungsi utama perbankan dalam sistem perekonomian antara lain sebagai wadah atau tempat menyimpan harta berupa uang, tempat untuk penyaluran dana serta fasilitas pengiriman uang. Hal tersebutsebagaimana definisi bahwa "bank adalah badan usaha yang menghimpun dana dari masyarakat dalam bentuk kredit dan atau bentuk lainnya dalam rangka meningkatkan hidup rakyat banyak (UndangUndang Nomor 10 Tahun 1998 Pasal 1 ayat 2).

Instruksi BI bukan tanpa alasan, melainkan bahwa bunga bank yang dibentuk berdasarkan pokok pinjaman membuat ekonomi masyarakat terhimpit. Sistem operasional bank konvensional tersebut berdasar suku bunga, dan Islam memastikan hal itu sebagai riba. Bunga menjadi riba karena tidak ada kepastian uang yang diterima oleh nasabah dimanfaatkan sehingga mendapatkan hasil, sementara persentase bunga sudah dipastikan tiap bulannya dari sejumlah pokok pinjaman. Majelis Ulama Indonesia telah memberikan fatwa haram terhadap bunga (Fatwa Dewan Syariah Nasional Nomor 1 Tahun 2004)

Dalam aspek perekonomian Islam berlaku kaidah fiqih " Al-ashl fi mu'amalah al-ibahah, segala sesuatu boleh dilakukan asalkan tidak bertentangan dengan hukum Islam (Putra, 2019:83), salah satu yang dilarang dalam hukum Islam adalah riba, larangan riba pada hakikatnya untuk mencegah ketidakadilan dan kedzaliman, yang pada akhirnya agar tercapai kesejahteraan masyarakat. Riba ada sejak zaman Jahiliyah. Setelah Islam datang, praktik perekonomian masyarakat yang mengandung riba dilarang atau diharamkan. Menurut Baraba, ekonomi Islam mengajarkan tiga pilar yaitu pilar aqidah, syariah dan akhlak (Baraba, 2003: 1-8). Dengan akhlak, maka manusia akan mampu membedakan yang haram dengan halal. Namun demikian, kondisi akhlak setiap orang berbeda, meskipun riba sudah dilarang, namun masih terdapat praktek ekonomi yang masih mengandung riba. Sikap waspada dan berhati-hati dalam bertransaksi khususnya yang berhubungan dengan jual beli dan bagi hasil dianggap perlu agar dapat terhindar dari perbuatan riba.

Dalam sistem operasional bank syariah, Islam memberikan solusi praktik muamalah agar terhindar dari unsur riba. Salah satu solusi yang ditawarkan adalah mekanisme pembagian keuntungan sehingga tepat bisa diterapkan bank syariah, apalagi pada masa darurrat kesehatan karena covid-19 yang ditujukan bagi nasabah, baik nasabah penabung maupun pembiayaan. Nasabah pembiayaan dengan sabar akan terus berusaha tanpa bayang-bayang target bunga yang harus dibayar, melainkan sesuai ketercapaian usaha yang dijalankan.

Tulisan singkat ini berisikan tentang dinamika pelarangan riba dalam Islam dan keuntungan pelarangan riba untuk mencapai kesejahteraan masyarakat di masa pandemi covid-19.

\section{KERANGKA KONSEPTUAL}

\section{Pengertian Riba}

Pemahaman terhadap riba dapat dilihat dari makna etimologis dan dan terminologis. 
Riba secara etimologis dapat diartikan sebagai kelebihan, penambahan, peningkatan atau surplus. Chapra mendefinsikan riba sebagai " riba literally means increase, addition, expansion or growth" (Arif, dkk, 2012:142). Definisi tersebut menunjukkan bahwa riba dikatakan sebagai peningkatan, tambahan, perluasan dan juga pertumbuhan. Menurut Zuhaili riba berdasarkan asal usul kata memiliki arti sesuatu yang bertambah (Zuhaili, 1998: 84). Makna yang sama menurut Imam sarkhasi, riba sebagai suatu atas bertambahnya baik nilai uang maupun barang pada pelaksanaan jual beli dengan meniadakan iwadh (kesamaan) (Sarkhasi \& Mabsut: 461). Pendapat lain tentang riba sebagaimana menurut Al-askalani, riba secara intrinsik berarti adalah suatu yang berlebih, dalam bentuk sejumlah nominal uang maupun barang. Gagasan yang senada sebagaimana menurut Al-Maududi bahwa riba adalah bertambahnya atas suatu yang dipinjam, baik dalam jumlah besar atau kecil (Nazir \& Hasanudin, 2008:562).

Riba dalam telaah terminologi dimaknai sebagai tambahan atas harta yang dimiliki yang diperoleh dari suatu transaksi, baik dalam transaksi hutang piutang, penjualan/pembelian, maupun tukar menukar suatu benda yang dapat merugikan salah satu pihak. Menurut Arif (2012:142) menghindarkan riba berarti meminimalisir orang mendapatkan keuntungan tanpa bekerja atau berusaha. Tambahan dalam jual beli merupakan bagian dari usaha atau bekerja, sedangkan tambahan dalam jual beli yang masuk kategori riba karena adanya tambahan timbangan, ukuran, maupun harga dari yang telah disepakati. Tambahan dalam hal hutang piutang memastikan bahwa tambahan tersebut tanpa melihat fungsi atas uang yang dipinjam atau dihutangkan, sehingga tambahan ini menjadi beban bagi penghutang.

\section{Macam-Macam Riba}

Riba memiliki macam-macam jenis yang biasa terjadi. Diantaranya adalah "riba utang piutang dan riba jual beli"(Sudarsono, 2008:15). Menurut Antonio, riba pada persoalan utang piutang terdiri dari riba qardh serta riba jahiliyah. Sementara riba yang terjadi pada penjualan/ pembelian antara lain riba fadhl dan riba nasi'ah (Antonio, 2001:41)

1. Riba qardh, merupakan pengambilan manfaat/nilai lebih dalam pengembalian suatu hutang, dan hal tersebut dipersyaratkan saat awal perjanjian (akad), tanpa mengetahui untuk apa kelebihan itu digunakan.

2. Riba jahiliyyah, ialah pengembalian atas pinjaman melebihi nilai harga semula yang disebabkan ketidakmampuan pembayaran tepat pada waktu yang ditentukan.

3. Riba nasi'ah, yaitu nilai tambah yang terjadi pada barter barang ribawi, karena penyerahan pada waktu yang berbeda.

4. Riba al-fadl, yaitu pertukaran antar barang yang memiliki jenis sama, tetapi diberikan dengan ukuran yang berbeda.

Pembagian riba menurut para ahli: pertama, menurut aliran Maliki, Hanabi dan Hambali terdiri dari riba nasi'ah serta riba al-fadl. Kedua, menurut imam Syafi'i, riba terdiri dari riba yad, nasi'ah dan fadl. Secara spesifik, pada riba yad dibagi menjadi riba pada saat barang diserahkan 
dengan waktu yang ditunda (Mugit, 2009:43).

\section{Pelarangan Riba dalam Islam}

Larangan riba tidak secara langsung, dalam hal ini Allah SWT menurunkannya secara bertahap. Berikut tahapan terhadap larangan riba:

1. Tahap I, riba disebut sebagai pinjaman yang seolah-olah menolong, memberikan tambahan bagi manusia, namun sesungguhnya tidak bertambah dihadapan Allah SWT (Qs. Ar-Rum: 39)

2. Tahap kedua, gambaran jelek terhadap pemakan riba yang diiringi dengan berbagai ancaman yang keras (Qs. an-Nisa: 160-161)

3. Tahap III, riba dikaitkan terhadap suatu tambahan yang bertumpuk-tumpuk (Qs. Ali Imran:130)

4. Tahapan ke IV, riba itu turun dalam bentuk wahyu Allah SWT riba itu haram, dari tambahan suatu yang dipinjamkan (Qs. al Baqarah: 278-279).

Pada tahap ke IV tersebut, dalam kalam Allah mulai menerangkan mengenai aturan serta sanksi dari orang yang melakukan riba. Penentuan sanksi hukum atas pelaku riba sebelum turunnya ayat tentang haram riba, maka tidak terkena sanksi, namun sebaliknya pelaku riba setelah haramnya riba, maka yang bersangkutan terkena sanksi hukum (Al-Hushari, 2014:166). Dengan demikian dapat disimpulkan bahwa segala sesuatu yang bertambah dari hutang seseorang maka dihukumi haram.

Larangan terhadap riba selain di bahas sebagaimana yang tertuang pada firman Allah, terdapat pula didalam sunnah Rasul SAW yakni:
1. Hadits Bukhari nomor 2034, di dalam sebuah kitab yang berjudul al Buyu. Abdurahman bin Abu Bakar meriwayatkan bahwa bapaknya menyampaikan, "Rasulullah SAW melarang penjualan emas dengan emas dan perak dengan perak kecuali sama beratnya, dan membolehkan kita menjual emas dengan perak dan begitu juga sebaliknya sesuai dengan keinginan kita.

2. Hadist yang diriwayatkan oleh Muslim nomor 2995, yang tertuang dalam kitab al-Masaqqah, bahwasannya "Jabir menyampaikan, Rasulullah saw. Membenci kepada seseorang atas ribayang diterimanya, dibayarkan, pencatat serta kedua saksi diantaranya"

Hadis terakhir pada 9 Dzulhijjah 10 Hijriyah, berisi tentang Rasulullah SAW memberi tekanan tentang riba, yang berisi: "Ingatlah bahwa kamu akan menghadap Tuhanmu dan Dia pasti akan menghitung amalanmu. Allah telah melarang kamu mengambil riba. Oleh karena itu, utang akibat riba harus dihapuskan. Modal (uang pokok) kamu adalah hakmu. Kamu tidak akan mende rita ataupun mengalami ketidakadilan." (Antonio, 2001:51-52).

\section{METODE PENELITIAN}

Penulisan paper ini mengunakan pendekatan kualitatif. Pembahasan dilakukan dengan analisis deskriptif. Data yang digunakan bersumber dari buku, jurnal dan observasi tidak langsung ke website Majelis Ulama Indonesia. Analisis dilakukan berupa analisis deskriptif, dengan memaknai dan menghubungkan setiap literatur yang berhasil didapat. 
PEMBAHASAN DAN HASIL

\section{Hikmah Dilarangnya Riba, Solusi Menghadapi Covid -19}

Agama Islam memerintahkan manusia agar melaksanakan sesuatu aktifitas, yang memberi nilai utama. Larangan terhadap suatu masalah, diyakini terdapat sifat mudharat. Adapun hikmah dibalik diharamkannya perbuatan riba di dalam agama Islam adalah sebagai berikut:

1. Manusia dijaga agar mengambil harta dengan cara yang baik atau dengan cara yang diharamkan oleh agama. Bunga memberikan ketidakadilan bagi salah satu pihak. Jika bank untung banyak, maka nasabah yang dirugikan karena menanggung bunga yang besar, begitu juga saat nasabah tidak mampu memberikan pendapatan dari uang yang dipinjam, maka akan semakin memberatkan nasabah. Kondisi seperti sekarang, yang lagi pandemi covid 19, usaha masyarakat banyak yang tertekan, maka dengan bagi hasil, kenyamanan bisnis nasabah tetap terjaga.

2. Arahan untuk investasi terhadap kekayaan yang dimiliki pada bidang bisnis yang bersih, halal, usaha yang diperbolehkan oleh agama, terhindar dari sikap curang sehingga kesulitan hidup dapat dicari solusi.

3. Dapat menghindarkan diri dari kesengsaraan. Kekayaan yang banyak yang diperoleh dengan cara yang salah tidak membawa keberkahan bagi pemiliknya. Berkah atas harta yang dimiliki berdampak pada kemudahan hidup, lancarnya beribadah, keturunan yang sehat.

4. Menghilangkan mental pemboros dan penumpukan harta pada satu tangan, yaitu sikap berfoya-foya pada saat orang lain kesulitan. Transaksi pada perbankan syariah, maka kesempatan nasabah untuk berperan aktif dalam mendorong orang lain memanfaatkan dana dengan menaruh trust pada bank syariah.

5. Menjadikan manusia lebih giat dalam bekerja, sabar dalam bekerja pada masa covid 19, sehingga tetap produktif. Keuntungan yang diperhitungkan dari hasil usaha akan semakin menambah giatnya seseorang berusaha.

Allah SWT telah menetapkan hukum sebagai suatu bentuk kebaikan bagi umatnya. Allah SWT melarang orang muslim memakan riba. Hal ini memberikan efek negatif bagi manusia. Setiap hal yang dilarang tentunya akan ada keberkahan ketika kita menjauhi perbuatan dosa tersebut, keberkahan itulah yang membawa umat muslim yang bertaqwa kepada Allah kedalam kehidupan yang tentram damai dalam menghadapi wabah pandemi covid 19. Hal ini diperlukan pemahaman bagi segenap masyarakat akan pentingnya menjauhi riba, agar rizqinya berkah dan membawa kemanfaatan duniawi dan ukhrawi.

\section{Bunga Versus Bagi Hasil}

Perbankan adalah institusi keuangan yang kegiatannya menerima simpanan uang dari masyarakat serta memberikan penyaluran dalam bentuk pinjaman. Perbankan konvensional dan perbankan syariah memiliki perbedaan. Sistem bunga dijalankan oleh perbankan konven, sedang bagi hasil diterapkan oleh bank syariah. Produk dana yang disalurkan oleh bank konven berupa kredit, dan istilah pembiayaan digunakan 
secara spesifik oleh bank syariah. Filosofi dalam pembiayaan yaitu terdapat objek yang dibiayai, sehingga riil harus dipastikan ada usaha yang dibangun.

Bank syariah memiliki suatu produk dalam pengelolaan portofolio pembiayaa diantaranya berdasar skema jual beli (murabahah, salam dan istishna'), sewa-menyewa (Ijarah dan IMBT), bagi hasil (mudharabah dan musyarakah), pinjam meminjam (qardh) dan jasa lainnya. Melihat dari produk tersebut, bank syariah sangat jauh berbeda dengan bank konvensional. Bank konvensional hanya memastikan dana tersalurkan secara aman, sedangkan pada bank syariah selain kepastian usaha aman, maka unsur halal menjadi pilihan utama. Produk tersebut tepat menjadi solusi bagi masyarakat dalam tetap menggerakkan ekonomi di masa covid 19. Dalam perbankan konvensional apabila terjadi masalah akan menempuh jalan penyelesaian melalui peradilan negeri sedangkan perbankan syariah penyelesaian masalah sesuai dengan tatacara dan hukum syariah. Bentuk hubungan nasabah dalam perbankan konvensional berbentuk kreditur-debitur dalam perbankan syariah bentuk nasabah adalah sebagai mitra. Perbedaan tersebut memastikan sebagaimana pendapat Suharto, bahwa bank syariah tidak saja bank bebas bunga, melainkan bank bebas ribawi (Suharto, 2018: 131-138).

Ketentuan di dalam sistem bunga, yaitu: besarnya persentase bunga didasarkan pada besarnya pinjaman, jadi semakin besar pinjaman yang dilakukan maka semakin besar pula tingkat suku bunganya, bunga ditentukan saat akad berlangsung dengan asumsi menguntungkan, pembayaran bunga dilakukan tanpa adanya pertimbangan apakah nasabah mengalami kerugianatau keuntungan, pembayaran bunga tidak dipengaruhi oleh keuntungan, jadi bunga tidak akan meningkat meskipun terjadi keuntungan, dan pemberlakuan bunga di haramkan dalam Islam. Dampak dari penerapan bunga menurut King dan Watson akan menjadikan rendahnya aktifitas sektor riil (King \& Watson, 1996). Tingginya suku bunga menjadikan kemampuan bisnis nasabah harus dijual tinggi, sehingga tidak mendapat respon positif bagi pembeli.

Sedangkan ketentuan pada pembiayaan bagi hasil, yaitu: besarnya nisbah atau bagi hasil tergantung pada keuntungan yang diperoleh nasabah, jadi jika laba yang di dapat saat wabah covid 19 ini banyak, maka jumlah nisbahnya dikalikan dengan keuntungannya, sehingga besar kecilnya mengikuti. Keuntungan yang dibagikan tergantung kepada keuntungan dan kerugian, bagi hasil ditentukan saat nisbah dibuat pada waktu akad dengan asumsi kemungkinan untung dan rugi, dan keabsahan bagi hasil tidak ada yang meragukan. Hal ini sebagaimana pendapat Marwini bahwa bunga memberikan dampak bagi perekonomian yaitu "pertama, sistem ekonomi ribawi menimbulkan krisis ekonomi, kedua, menimbulkan kesenjangan pertumbuhan ekonomi, ketiga, menimbulkan inflasi, keempat, menjerumuskan negara berkembang ke dalam hutang"( Marwini, 2017:1-18). Meniadakan bunga dan menghadirkan bagi hasil akan memunculkan keadilan sehingga perekonomian merata, inflasi akan menyesuaikan karena daya beli masyarakat meningkat, dan dengan sejahtera maka masyarakat akan terhindar dari hutang yang bersifat konsumtif. 
Keuntungan Penerapan Sistem Bagi Hasil dalam Perbankan Syariah

Keuntungan penerapan bagi hasil dalam perbankan meliputi:

1. Mekanisme bagi hasil didasarkan pada prinsip efisiensi dan keadilan sehingga tidak akan terjadi kesenjangan ekonomi. Dimana bagi hasil dibagikan secara adil antara pihak bank dan nasabah sesuai dengan nisbah.

2. Tidak terpengaruh dengan naikturunnya sistem bunga yang berlaku sehingga penerapan sistem bagi hasil cenderung lebih stabil dan tidak menakutkan bagi nasabah, apalagi pandemi covid 19, sehingga sistem bagi hasil sinergi dengan seberapa capaian nasabah.

3. Dengan adanya Dewan Pengawas Syariah akan terhindar dari praktik Money Laundering.

4. Pemberian kredit pembiayaan sangat selektif sehingga terhindar dari usaha-usaha yang diharamkan dan terhindar dari praktik riba.

5. Apabila terjadi kredit macet akibat usaha yang dilakukan mengalami kebangkrutan Bank Syariah akan melakukan soft approach kemudian baru hard approach, sedangkan bank konvensional akan melakukan tindakan eksekusi apabila semua langkah penyelamatan gagal seperti mengambil aset nasabah.

Kekurangan dari bagi hasil yaitu kurangnya kesadaran atau itikad baik dan keahlian pengelola usaha yang berdampak pada majumundurnya suatu usaha. Hal ini disebabkan karena semua kendali pekerjaan berada di tangan pengelola usaha. Pemilik modal harus mengetahui karakteristik, latar belakang pengelola perusahaan dan usaha yang dilakukan agar mengetahui perkembangan dari modal yang dipinjamkan sehingga adanya unsur keterbukaan dari kedua belah pihak.

Kredit sepeda tidak termasuk riba. Sebab dalam perbankan syariah terdapat beberapa akad yang biasa digunakan dalam kredit (pembiayaan) sepeda. Yang pertama yaitu Ijarah Muntahiya bi tamlik yang merupakan sewa dengan berakhirnya perpindahan kepemilikan akan barang tersebut. Yang kedua wakalah, bank hanya sebagai wakil atau perantara antara nasabah dengan penyedia. Dalam hal ini bank menjalin kerja sama dengan penyedia.

Keuntungan dikatakan riba apabila sebagian pihakyang berakad dirugikan dan tidak disepakati antar pihak yang berakad. Tidak ada batasan berapa persen keuntungan dikatakan riba asalkan keuntungan diketahui kedua belah pihak sejak awal akad. Objek yang di akadkan juga harus diketahui hal ini lah yang menjadikan keuntungan tersebut bukan riba.

\section{Kesejahteraan di Masa Pandemi Covid 19}

Al-Ghazali berpendapat bahwa kesejahteraan merupakan terwujudnya kemaslahatan. Kemaslahatan dikenal sebagai Maqasid alSyariah. Adapun sumber kesejahteraan antara lain karena "terpeliharanya agama, jiwa, akal, keturunan dan harta"(Rohman, 2010: 84-86). Konsep sejahtera yang diterapkan dalam sistem perekonomian Islam merupakan kesejahteraan secara menyeluruh, dikatakan demikian karena kesejahteraan ini mencangkup kesejahteraan material dan kesejahteraan spiritual. Hal yang mendukung terwujudnya sejahtera material dan spiritual didorong oleh nilai moralitas.

Pelarangan Riba dalam Perbankan $\| 7$ 
Hal tersebut berbeda dengan sistem ekonomi konvensional. Dalam sistem konvensional konsep kesejahteraan hanya mencangkup kesejahteraan material saja, yaitu kesejahteraan dapat tercapai jika setiap factor dalam produksi dan distribusi barang sudah teralokasikan dengan sempurna sehingga tercapai keseimbangan yang ideal. Saat ukuran material yang dikejar, ketika wabah melanda, institusi bank konvensional tidak bisa berbuat banyak, selain memenuhi instruksi gubernur BI untuk menurunkan suku bunga kredit.

Menurut Sardar (2016:394), kesejahteraan dalam pandangan yang lebih luas didefinisikan sebagai berikut, yaitu:

1. Sejahtera secara seimbang serta holistik, yakni tercukupinya kebutuhan secara spiritual individu dan masyarakat secara sosial. Kebahagiaan seseorang terwujud tatkala seimbang antara diri dan sosial. Pada musim pandemi ini, dengan bagi hasil bank syariah, nasabah bank syariah bisa bisnis dari rumah, sehingga tetap bisa produktif.

2. Sejahtera duniawi dan ukhrawi (tercapainya falah). Tercukupinya kebutuhan duniawi sarana untuk beribadah untuk ketercapaian tujuan yang kekal yaitu ukhrawi.

Kesejahteraan dari dampak pelaksanaan perbankan syariah di Indonesia sudah dirasakan oleh masyarakat. Dimana perbankan syariah dapat mengurangi ketimpangan sosial yang terjadi di Indonesia dan menjadi stimulus pertumbuhan ekonomi. Dilarangnya pemakaian riba menjadikan peluang untuk perbankan syariah dalam menciptakan perekonomian yang sehat dan positif. Menganggap nasabah sebagai mitra kerja dengan membagi risiko kerugian dan keuntungan sehingga apabila terjadi kerugian dalam usaha nasabah atau masyarakat mereka merasa diringankan sebab bank juga menanggung resiko kerugian. Menurut Hasanah, peran bank syariah memberikan dukungan atas suksesnya usaha nasabah, sehingga berdampak bagi kesejahteraan (Hasanah, 2014:23). Identifikasi sejahtera pada nasabah dapat dilihat dari peningkatan usaha nasabah, dan terpenuhinya kebutuhan konsumen dari hasil transaksi tersebut.

Kestabilan ekonomi juga akan dirasakan apabila mengenakan produk perbankan syariah. Kestabilan ekonomi bisa terjadi sebab perbankan syariah tidak terpengaruhi oleh naik turunnya suku bunga dimana ketentuan nisbah tetap yang disepakati dari awal akad. Dampak dari hal tersebut, masyarakat akan terus produktif dari dana yang telah disalurkan oleh bank syariah. Masyarakat juga mendapatkan kenyamanan dimana dengan menggunakan layanan perbankan syariah dapat menghindari larangan-larangan agama. Oleh sebab itu perbankan syariah tidak hanya memberikan kesejahteraan di dunia namun juga di akhirat.

\section{PENUTUP}

Permasalahan yang ditimbulkan karena adanya sistem bunga (riba), yaitu: adanya ketidakadilan dalam praktik perekonomian. Hal itu terasa pada saat covid 19 melanda. Nasabah sulit mendapatkan keuntungan, sementara bunga bank wajib dibayar tiap bulannya. Bunga pada bank konvensional menjadi pendukung kredit 
macet di perbankan konvesional, tingginya rate kredit dan berlipat-lipat mengakibatkan kesulitan nasabah membayar, kehidupan ekonomi masyarakat tidak menentu. Hal ini bunga menjadi salah satu faktor penyebab inflasi dan munculnya kesenjangan ekonomi dan konglomerasi kekayaan. Karena hal itulah DSN dalam fatwanya No 1 tahun 2004 menghukumi bunga adalah riba.

Upaya menghindarkan masyarakat menggunakan praktik riba di atas, bank syariah memberikan solusi dengan menerapkan sistem bagi hasil. Sistem bagi hasil memberikan efek keadilan dan kesejahteraaan. Dampak keadilan ekonomi menjadikan ekonomi merata, inflasi akan menyesuaikan karena daya beli masyarakat meningkat, dan dengan sejahtera maka masyarakat akan terhindar dari hutang yang bersifat konsumtif.

\section{DAFTAR KEPUSTAKAAN}

Al-Hushari, Syaikh Ahmad Muhammad. 2014. Tafsir Ayat-Ayat Ahkam: Telaah Ayat-ayat Hukum Seputar Ibadah, Muamalah, Pidana dan Perdata (terjemahan). Jakarta: Pustaka Al-Kautsar

Antonio, M. Syafi'e. 2001. Bank Syariah dari Teori ke Praktek. Jakarta: Gema Insani

Arif, Muhammad, Ashiq Hussain, and Muhammad Azzem. "Riba Free Economy Model." International Journal of Humanities and Social Science 2, no. 6 (2012). www.ijhssnet.com As-Sarkhasi, Al-Mabsut, (Mauqi al-Islam, tanpa tahun), Vol 14, 461
Baraba, Achmad, 2003. Prinsip Dasar Operasional Perbankan Syariah, Buletin Ekonomi Moneter dan Perbankan 2, no. 3 (October 11)

Fatriani, Rini. 2018. Bentuk-Bentuk Produk Bank Konvensional dan Bank Syariah di Indonesia. Ensiklopedia of Journal Vol. 1 No.1 Edisi 2

Fatwa Dewan Syariah Nasional Nomor 1 Tahun 2004 Tentang Interest (fa'idah)

Hasanah, Uswah, 2014. Riba dan Bunga Bank dalam Perspektif Fiqh," Wahana Inovasi 3, no. 1

King, Robert G. and Mark W. Watson, 1996. Money, Prices, Interest Rates and the Business Cycle (National Science Foundation through Grants), accessed April 14, 2020, https://www.jstor. org/stable/2109846?origin=crossref

Laucereno, Sylke Febrina, Gubernur BI: Kami minta perbankan segera turunkan bunga kredit! Diakses melalui https://finance. detik.com/moneter/d-4951911/gubernurbi-kami-minta-perbankan-segera-turunkanbunga-kredit

Marwini. 2017. Kontroversi Riba dalam Perbankan Konvensional dan Dampaknya Terhadap Perekonomian. 09 (01): 1-18.

Mugits, Abdul, 2009. Ketidakpastian Jenis dan Kriteria Hukum Riba, Jurnal As-Syir'ah, Vol. 43

Nazir, Habib, Muhammad Hasanuddin, 2008. Insiklopedi Ekonomi dan Perbankan Syariah, cet. II, (Bandung: Kafa Publishing)

Putra, Muhammad Deni, 2019. "Jual Beli Online Berbasis Media Sosial dalam Perspektif Hukum Islam". Iltizam Journal of Sharia Economic Research", Vol. 3, No.1

Pelarangan Riba dalam Perbankan |9 
JURNAL IMARA

Rohman, Abdur. 2010. Ekonomi Al-Ghazali,

Suharto, Ugi, 2018. Riba and Interest in Islamic Menelusuri Konsep Ekonomi Islam Ihya'Ulum al-Din. Surabaya: Bina Ilmu.

Finance: Semantic and Terminological Issue, International Journal of Islamic and Middle

Sardar, Ziauddin. 2016. "Kesejahteraan Dalam Perspektif Islam Pada Karyawan Bank Syariah". Jurnal Ekonomi Syariah Teori dan Terapan.3 (5).

Sudarsono, Heri, 2008. Bank dan Lembaga Eastern Finance and Management 11, no. 1 (April 16)

Zuhaili, 1998. Tafsir al- Munir fi al-Aqidah wa as-Syariah wa al-Manhaj (Bierut: Dar al-Fikr al-Muashir)

Keuangan Syariah, Deskripsi dan Ilustrasi, edisi 3, (Yogyakarta: Ekonisia)

$10 \mid$ Binti Nur Aisyah, Nur Azrin Yuliani, Evita Amelia, dan Fifin Nasiroh 